\section{PREDATORY RED SQUIRRELS}

PETER TAYLOR, P.O. Box 597, Pinawa, Manitoba. ROE 1L0

Nero recently reported a Red Squirrel killing a House Sparrow at a bird feeder, and reviewed published information on predatory behaviour by this squirrel. ${ }^{2}$ This has prompted me to document an observation of apparent predation by a Red Squirrel on young Snowshoe Hare, and a report of a bird-killing squirrel.

At about 7:00 one morning in late April or May 1982, in an area of mainly deciduous woodland on the edge of Pinawa, a Red Squirrel was observed carrying a small mammal through the trees about $5 \mathrm{~m}$ overhead. At first, 1 thought it was transferring young from one nest to another. Disturbed by a human presence, however, it dropped its burden, which proved to be a freshly dead Snowshoe Hare leveret, no more than a few days old. Although the squirrel may have found the hare dead, it seems likely that it killed it, given this species' known carnivorous tendencies. Snowshoe Hare is not among the prey cited by Nero, but the list does include young Eastern Cottontails. ${ }^{2}$
Nero cites a comment by Klugh that only certain Red Squirrels are birdeaters. ${ }^{2}$ The following casual observations would seem to support this. Red Squirrels at our feeders have always seemed tolerant of birds and I have not observed any serious antagonism in almost 10 years of feeder operation. Other Pinawa residents, however, have told me of squirrels repeatedly harassing birds at feeders. Although such activity is usually confined to driving birds away from food, I received one report of a squirrel killing birds. Unfortunately, I did not obtain further details and the observer (A.E. Weissig) is no longer resident in Pinawa.

Bob Nero's killer squirrel later also evidently tried but failed to capture a Mourning Dove. On 1 August 1987 at about 3:00 p.m., Ruth Nero was startled by a noise and looked up to see a Red Squirrel on top of a bird feeder with a mouthful of feathers. Later Bob found a patch of Mourning Dove feathers on the ground beneath the feeder (pers. comm., January 1988).

1 KLUGH, A.B. 1927. Ecology of the Red Squirrel. J. Mammalogy 8:1-32.

2 NERO, R.W. 1987. House Sparrow killed by Red Squirrel. Blue Jay 45:180-181.

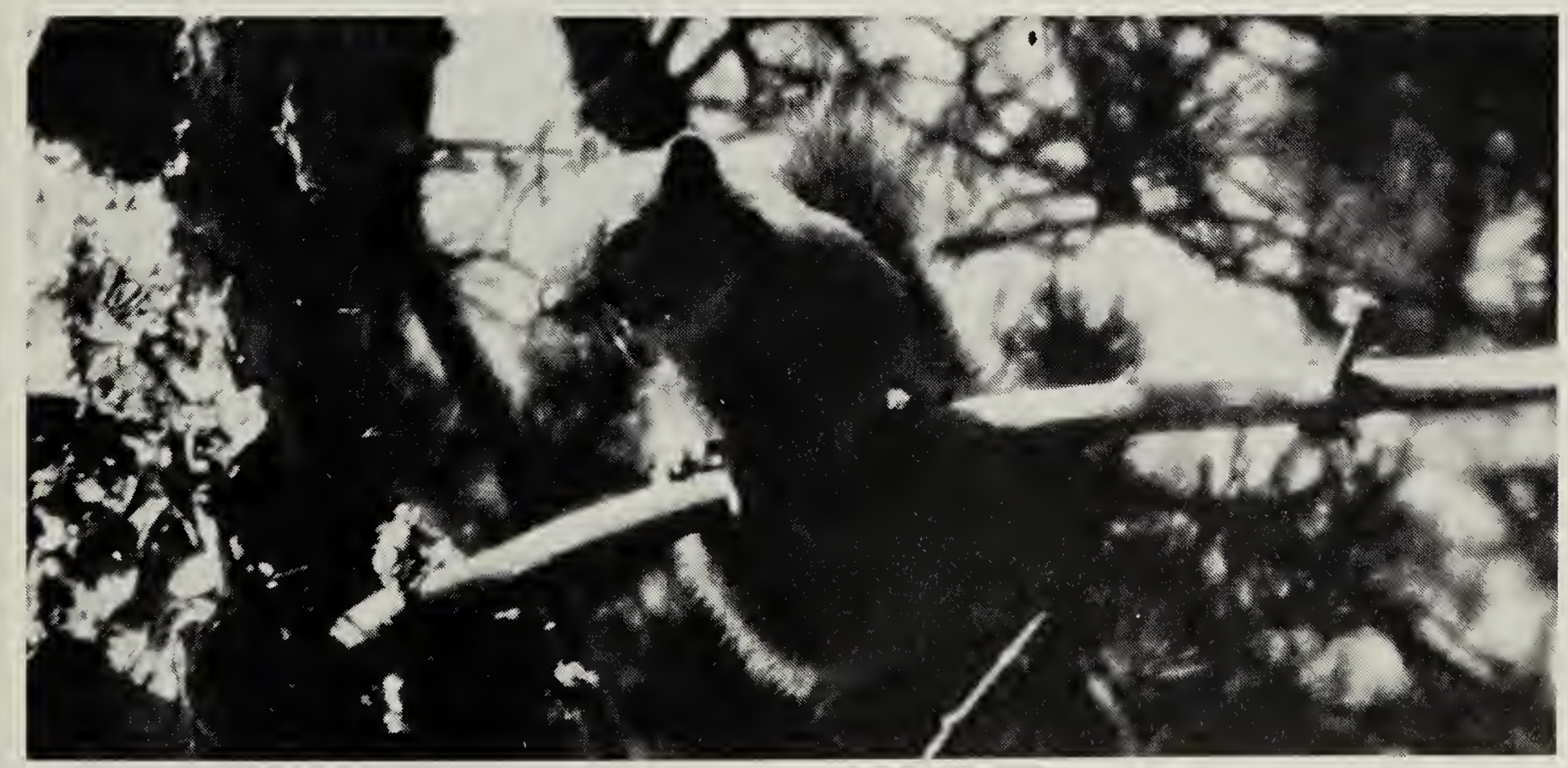

Red Squirrel

Fred Lahrman 